\title{
СТРУКТУРНО-ЛІНГВІСТИЧНИЙ ПІДХІД ДО ОЦІНКИ ДОВГОТРИВАЛОЇ АДАПТАЦІЇ СПОРТСМЕНІВ ВИСОКОЇ КВАЛІФІКАЦІЇ ДО УМОВ СЕРЕДНЬОГІР'Я
}

\author{
Л. І. Черкес ${ }^{1}$, В. М. Ільїн ${ }^{2}$, В. І. Портниченко ${ }^{1}$, М. М. Михайлович ${ }^{3}$, І. О. Яхниця ${ }^{1}$ \\ С. Б. Коваль ${ }^{2}$
}

Міжнародний центр астрономічних $і$ Національна медична академія післядипломної освіти імені П. А. Шупика МОЗ України² Чернівецький національний університет імені Ю. Федьковича ${ }^{3}$

\begin{abstract}
Внаслідок адаптації до хронічної гіпоксії у спортсменів зникли спектри потужності серцевого ритму, що характерні для нестійких функціональних станів, пов'язаних з високою напругою регуляторних механізмів та підвищеним ризиком спонтанного переходу у стани наднапруги або виснаження. На 10-12 добу перебування у гірських умовах у всіх спортсменів у стані спокою були відсутні стани функціональної напруги, наднапруги і виснаження регуляторних механізмів. Під час проведення активної ортопроби у спортсменів не виникали стани наднапруги $\mathrm{i}$ виснаження та спостерігалось значно менше станів з функціональною напругою.
\end{abstract}

Ключові слова: гіпоксія, адаптація, серцевий ритм, спектральна формула, ортопроба.

\section{СТРУКТУРНО-ЛИНГВИСТИЧЕСКИЙ ПОДХОД К ОЦЕНКЕ ДОЛГОВРЕМЕННОЙ АДАПТАЦИИ СПОРТСМЕНОВ ВЫСОКОЙ КВАЛИФИКАЦИИ К УСЛОВИЯМ СРЕДНЕГОРЬЯ}

\author{
Л. И. Черкес ${ }^{1}$, В. Н. Ильин ${ }^{2}$, В. И. Портниченко ${ }^{1}$, М. Михайлович ${ }^{3}$, И. А. Яхница ${ }^{1}$, \\ С. Б. Коваль ${ }^{2}$ \\ Международный центр астрономических и медико-экологических исследований \\ НАН Украины ${ }^{1}$ \\ Национальная медицинская академия последипиомного образования \\ имени П.А. Шупика МЗ Украины ${ }^{2}$ \\ Черновицкий национальный университет имени Ю. Федьковича ${ }^{3}$
}

\begin{abstract}
В результате адаптации к хронической гипоксии у спортсменов исчезли спектры мощности ритма сердца, характерные для неустойчивых функциональных состояний, связанных с высоким напряжением регуляторных механизмов и повышенным риском спонтанного перехода в состояния перенапряжения и истощения. На 10-12 сутки у всех спортсменов в покое отсутствуют состояния функционального напряжения, перенапряжения или истощения регуляторных механизмов. При проведении активной ортопробы у спортсменов не возникают состояния перенапряжения или истощения и наблюдается значительно меньше состояний с функциональным напряжением.
\end{abstract}

Ключевые слова: гипоксия, адаптация, сердечный ритм, спектральная формула, ортопроба.

\section{STRUCTURAL AND LINGUISTIC APPROACH TO THE ASSESSMENT OF LONGTERM ADAPTATION OF HIGH QUALIFICATION SPORTSMEN TO MIDDLE ALTITUDE CONDITIONS}

L. I. Cherkes ${ }^{1}$, V. M. llyin' ${ }^{2}$, V. I. Portnychenko ${ }^{1}$, M. M. Mykhailovych ${ }^{3}$, I. O. Yakhnytsa', S. B. Koval ${ }^{2}$

International Centre for Astronomical and Medico-Ecological Research of NAS of Ukraine ${ }^{1}$ National Medical Academy of Post-Graduate Education named after P. L. Shupyk of the Ministry of Public Health of Ukraine ${ }^{2}$ Chernivtsi National University by Yu. Fedkovych ${ }^{3}$ 
After adaptation to chronic hypoxia, in athletes the power spectra of heart rhythm typical for the unstable functional states associated with high strained regulatory mechanisms, and with increased risk of spontaneous transition in the state of overload and exhaustion, were disappeared. At 10-12 days, all the athletes at rest had not functional state with high strain, overload or depletion of regulatory mechanisms. During active orthostatic test, in sportsmen were not occurred the states with exhaustion or overloading and functional strained states were significantly rare observed.

Key words: hypoxia, adaptation, heart rate, spectral formula, orthostatic test.

Вступ. При розробці технології оцінки функціонального стану організму людини при дії екстремальних чинників важливим $є$ питання вибору базової фізіологічної функції, аналіз змін якої буде покладений в основу цієї оцінки. Така функція повинна задовольняти принаймні двом критеріям: iі можна легко реєструвати в складних екстремальних умовах, і вона у меншій мірі повинна підпадати під регулювальний вплив свідомості обстежуваної людини [1, 2]. Згідно з думкою багатьох дослідників, цим двом критеріям найкраще відповідає серцевий ритм [3-5]. Проте, попри те, що робіт, пов'язаних з аналізом варіабельності серцевого ритму досить багато, подальша його інтерпретація здійснюється часто інтуїтивно, без урахування закономірностей трансформації функціональних станів організму [2].

Для усунення цього недоліку в нашій роботі вико ристаний структурно-лінгвістичний аналіз варіабельності серцевого ритму, який заснований на трьох постулатах, що враховують фундаментальні властивості живих організмів. По-перше, в процесі розвитку живих систем існують певні закономірності трансформації функціональних станів організму в динаміці його життєдіяльності [6]. По-друге, функціональні стани організму можна досить повно описати за допомогою невеликої кількості символів, що відображають активність окремих компонент, які визначають функціональний стан організму в різних ситуаціях [6, 7]. По-третє, враховується положення про те, що живий організм є ультрастабільною системою [8].

Метою роботи $є$ оцінка за допомогою структурно-лінгвістичного методу змін функціональних станів організму людини в процесі довготривалої адаптації до умов гіпобаричної гіпоксії на прикладі висококваліфікованих спортсменів, що спеціалізуються в швидкісно-силових видах легкої атлетики.

Організація та методи дослідження. В умовах середньогір'я на висоті 2100 м на базі Ельбруської медико-біологічної станції Міжнародного центру астрономічних і медико-екологічних досліджень НАН України на 10-12 добу перебування в горах обстежені 12 спортсменів кваліфікації майстер спорту і майстер спорту міжнародного класу, членів збірної України, що спеціалізуються у бігу на середні дис- танції 400 і 800 м. Усі спортсмени брали участь в кардіоритмографічному обстеженні в стані відносного спокою лежачи і при проведенні активної ортостатичної проби (АОП).

Відповідно до "Міжнародного стандарту" [9] у дослідженнях тривалість запису КРГ складала 5 хвилин (300 c). При проведенні АОП проводився аналіз як нестаціонарної ділянки кардіоритмограми (КРГ), що характеризує перехідний процес після прийняття положення стоячи тривалістю 1 хвилина, так і стаціонарної ділянки, що йде за нею.

Для класифікації КРГ і оцінки зміни функціонального стану організму спортсменів під час хронічної дії гіпобаричної гіпоксії був застосований структурнолінгвістичний метод, апробований раніше при оцінці функціонального стану регуляторних систем організму цих же спортсменів в початковий період перебування в горах [10].

Результати роботи та їх обговорення. При аналізі КРГ спортсменів, зареєстрованих на 10-12 добу перебування в умовах середньогір'я у спокої і при проведенні активної ортопроби, визначені 7 з 16 можливих типів спектрів потужності серцевого ритму, а саме Sb, Sm, SmSb, SbSm, SmSbSf, SmSfSb,

$\mathrm{SbSmSf}$ (рис. 1). В порівнянні з початковим періодом перебування в горах [10], в результаті адаптації до хронічної гіпоксії у спортсменів зникли спектри потужності серцевого ритму з переважанням надвисокочастотного компонента Sf, які свідчать про наявність нестійких функціональних станів, пов'язаних 3 високою напругою регуляторних механізмів і підвищеним ризиком спонтанного переходу в стани перенапруження і виснаження.

Найчастіше зустрічалися спектри типу $\mathrm{SmSb}$ $(19,4 \%)$ i $\operatorname{SbSm}(19,4 \%), \operatorname{SmSbSf}(19,4 \%)$ i SbSmSf $(19,4$ \%). Слід зазначити високий відсоток (21\%) спектрів, що містять високочастотний (Sb) компонент (Sb, SbSm, SbSmSf) і характеризують у спортсменів стани з високою тренованістю, у яких повна адаптація до чинників зовнішнього середовища забезпечується за рахунок підвищених витрат енергетичних і структурних елементів в організмі $[3,11]$.

На рисунку 2 наведена частота виявлення різних типів спектрів потужності кардіоритмограм за різних 


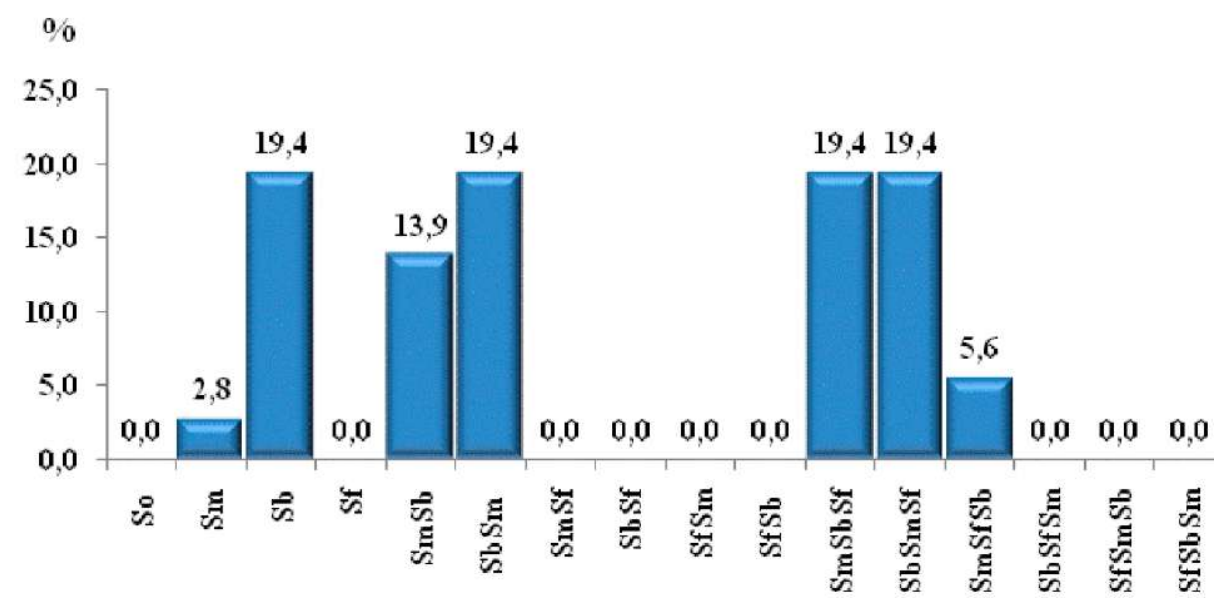

Puc. 1. Частота виявлення різних типів спектрів серцевого ритму у спортсменів на 10-12 добу перебування в умовах середньогір'я.

\section{Стан спокон}

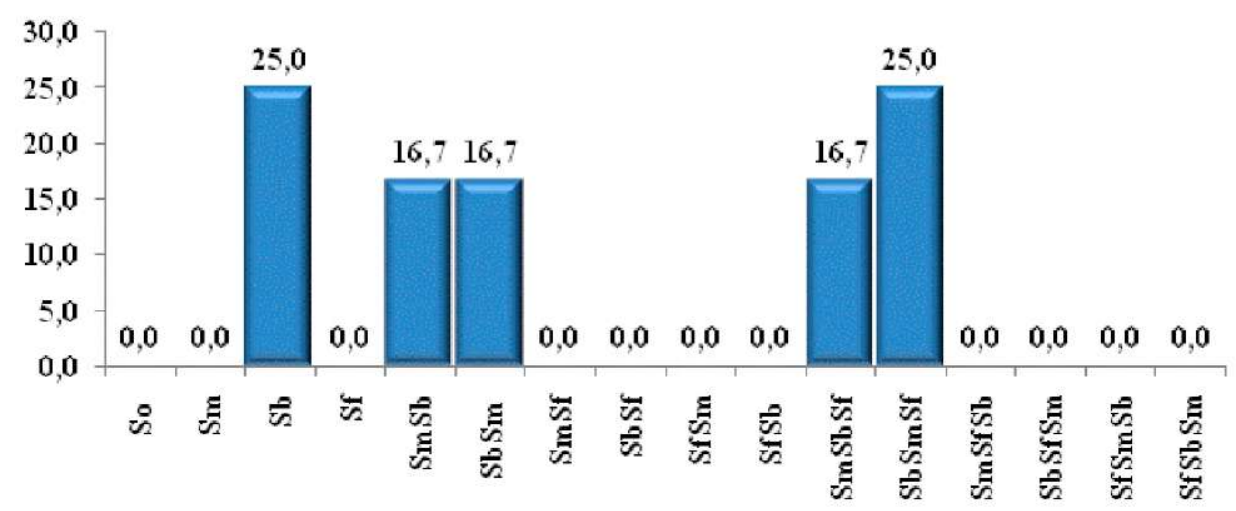

Ортопроба

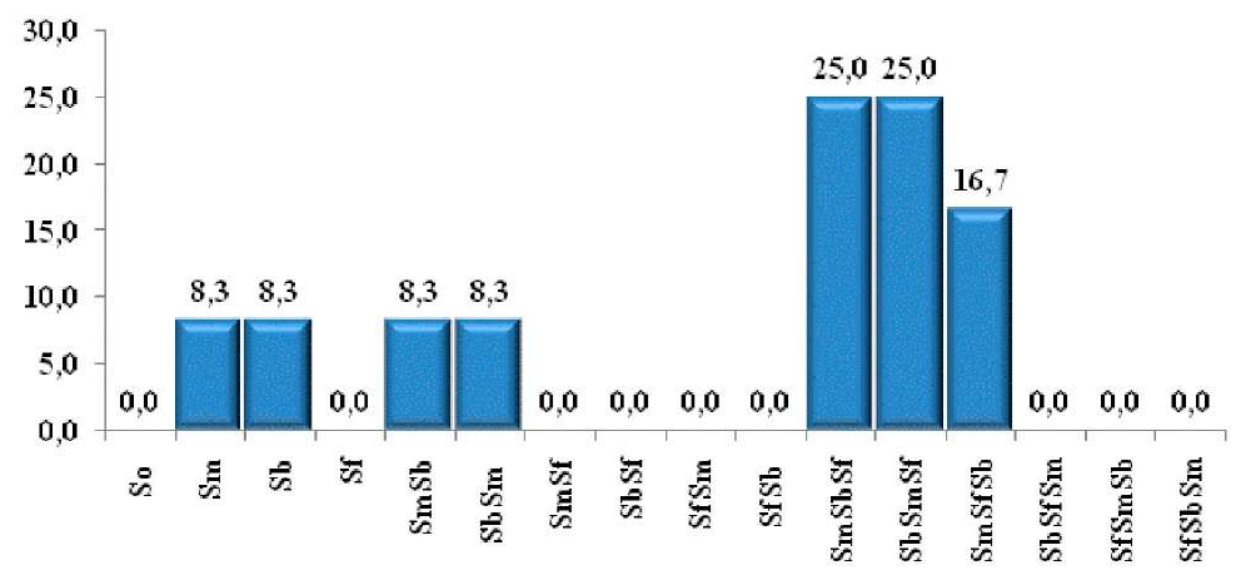

Puc. 2. Розподіл типів серцевого ритму у спортсменів в стані відносного спокою і при проведенні активної ортопроби на 10-12 добу перебування в умовах середньогір'я.

умов їх реєстрації на 10-12 добу перебування в умовах середньогір'я.

На відміну від початкової фази адаптації [10], реакція організму спортсменів на ортопробу була адекватнішою. Відсутні спектри So, SmSf, SbSf, SfSmSb, що вказують на високу напругу регуляторних сис- тем організму. Знижений відсотковий вміст кардіоритмограм із спектрами, що містять високочастотний компонент (Sb) і характеризують функціональну напругу регуляторних систем організму спортсменів. На 10-12 добу перебування в умовах середньогір'я (рис. 3) практично у всіх спортсменів у спокої 


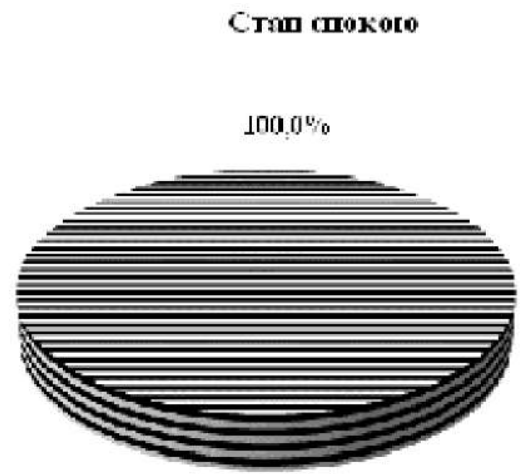

Opromôna

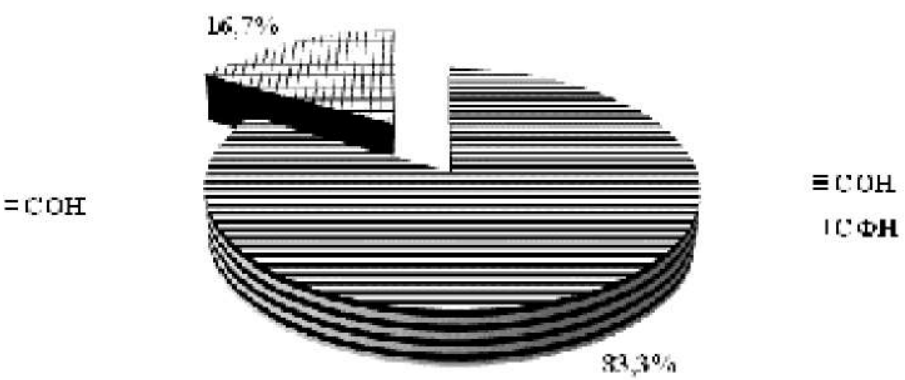

Puc. 3. Розподіл станів оптимального (СОН - SmSb, SmSbSf, SbSm, SbSmSf), функціонального (СФН - Sm, $\mathrm{SmSf}, \mathrm{SmSfSb}, \mathrm{SfSmSb}$, Sb; SbSf, SbSfSm) напруження, перенапруження і виснаження (СП і CB - So) регуляторних

відсутні стани функціональної напруги (СФН), перенапруження (СП) або виснаження регуляторних механізмів (СВ). При проведенні активної ортопроби у спортсменів на 10-12 добу не виникають стани перенапруження або виснаження. Спостерігається значно менше станів $з$ функціональною напругою. Так, якщо в початковій фазі вони складали 62,5 \% від усіх зареєстрованих станів, то в процесі 10-12-добової адаптації до хронічної гіпоксії - лише $16,7 \%$.

Висновки. 1. Внаслідок адаптації до хронічної гіпоксії у спортсменів зникли спектри потужності серцевого ритму з переважанням надвисокочастотного компонента Sf, які свідчать про наявність нестійких функціональних станів, пов'язаних з високою напругою регуляторних механізмів і підвищеним ризиком спонтанного переходу в стани перенапруження і виснаження. Відзначається високий відсоток (21 \%) спектрів потужності серцевого ритму, характерних для станів з високою тренованістю.

2. На 10-12 добу в усіх спортсменів в спокої відсутні стани функціональної напруги, перенапруження або виснаження регуляторних механізмів. При проведенні активної ортопроби у спортсменів не виникають стани перенапруження або виснаження і спостерігається значно менше станів з функціональним напруженням регуляторних систем організму.

\section{Література}

1. Яблучанский Н. И. Основы практического применения неинвазивной технологии исследования регуляторных систем человека / Н. И. Яблучанский, А. В. Мартыненко, А. С. Исаева. - Х. : Основа, 2000. - 88 с.

2. Ритмокардиографические методы оценки функционального состояния организма человека / В. Н. Ильин, Л. М. Батырбекова, М. Х. Курданова, Х. А. Курданов. - М. : Илекса; Ставрополь : Сервисшкола, 2003. - 80 с.

3. Баевский Р. М. Математический анализ изменений сердечного ритма при стрессе / Р. М. Баевский, О. И. Кириллов, С. З. Клецкин. - М. : Наука, 1984. - 221.

4. Сапова Н. И. Комплексная оценка регуляции ритма сердца при дозированных функциональных нагрузках / Н. И. Сапова // Физиол. журн. СССР. - 1982 - Т. 68, №8. - С. 1159-1164.

5. Михайлов В. М. Вариабельность ритма сердца: опыт практического применения метод / В. М. Михайлов. - Иваново : Иван. Гос. Мед. Академия, 2002. - 290 с.

6. Ільїн В. М. Структурно-лінгвістичний підхід до оцінки функціонального стану організму людини / В. М. Ільїн, В. В. Кальниш, Х. А. Курданов // Доп. НАНУ -2001 . -№ 6. - С.185-189.
7. Basar E. An analysis of portal vein spontaneous contractions / E.Basar, C.Eroglu, P.Ungan // Plugers Arch. 1974. - V. 352. - Р. 135-140.

8. Эшби У.Р. Конструкция мозга / У.Р.Эшби. - М.: Изд. иностранной литературы, 1962. - 398 с.

9. Task Force of the European of Cardiology and the North American Society of Pacing and Electrophysiology. Heart Rate Variability. Standarts of Measurements, Physiological Interpretation, and Clinical Use/ // Circulation. -1996. - 93.P. 1043-1065.

10. Структурно-лингвистический подход к классификации кардиоритмограмм у спортсменов высокой квалификации в начальную фазу адаптации кусловиям среднегорья / В. Н. Ильин, Л. И. Черкес, М. Михайлович [и др.] // Медична інформатика та інженерія. - 2011. - № 3. - С. 27-33.

11. Ilyin V. The structure-linguistic approach to evaluation of functional state of human organism in the extreme conditions / V. Ilyin, V. Kalnysh, Y. Gorgo // Сб. трудов конф. «Автоматизированный анализ гипоксических состояний», НальчикМосква, 2003. - С.141-145. 